\title{
Beslenme ve Gida Alanlarında Metabolomik Uygulamalar: Genel Bir Değerlendirme
}

\author{
İlkay YILMAZ*, Haydar ÖZPINAR **
}

\section{$\ddot{O} \mathbf{z}$}

Metabolomik, küçük moleküllü metabolitlerin lipitler, karbonhidratlar, vitaminler, hormonlar ve dokularda, hücrelerde ve fizyolojik sıvılarda bulunan diğer hücre bileşenlerinde belirli bir sürede yüksek verim teknolojilerini kullanarak belirlenmesi, nicelendirilmesi ve tanımlanmasıdır. Metabolomik uygulaması, biyobelirteçlerin tanımlanmasını, enzim-substract etkileşimlerini, ilaç aktivitesi çalışmalarını, metabolik yol analizini ve sistem biyolojisi ile ilgili diğer bazı çalışmaları içerir. Yani metabolomik, NMR, GC-MS ve LC-MS gibi yüksek verimli teknolojilerle hücrelerde, dokularda veya biyolojik sıvılarda bulunan tüm metabolitlerin kısa sürede ucuz ve doğru ayrılması, tanımlanması ve ölçülmesidir. Beslenme paternleri ve toksinlere maruz kalma gibi çevresel faktörler, obezite, tip 2 diyabet gibi birçok hastalığın önlenmesinde/ gelişmesinde ve dolayısıyla kişilerin sağlık durumlarında önemli bir rol oynar. Sağlıklı olmak, iyi genetik, iyi yaşam tarzı ve iyi beslenmenin bir birleşimidir. Metabolomik, metabolit konsantrasyonlarını izleyerek fizyolojik işlemlerin analizini sağlar, büyük ölçüde yiyeceğin moleküler içeriğine ve sağlı özelliklerine göre değişebilen ve gıda işlemesinin bir sonucu olarak oluşan kimyasal değişiklikleri karakterize eder. Günümüzde bilim insanarı obezite, diyabet, kardiyovasküler ve kronik hastalıkların önlenmesi ve yaşamı uzatan, kilo verdiren, fiziksel ve zihinsel sağlığı geliştiren ve kalp krizi ve kanser gibi hastalıkları önleyen yeni biyoaktif gıda bileşenleri bulmak için çalışmaktadır. Bu bağlamda, metabolomik tekniklerin kullanımı, gıda tüketim modellerinin geliştirilmesi, herhangi bir diyetin faydaları ve fizyolojik tepkilerin iyileştirilmesine yönelik çalışmalara katkı sunmaktadır. Bu konuda gıda bilimi ve

\section{Derleme Makale (Review Article)}

Geliş / Received: 28.05 .2019 \& Kabul / Accepted: 12.07.2019

* Dr. Öğr. Üyesi, İstanbul Ayvansaray Üniversitesi, Güzel Sanatlar, Tasarım ve Mimarlık Fakültesi, Gastronomi ve Mutfak Sanatları Bölümü, İstanbul, Türkiye,

E-posta: ilkayyilmaz@ayvansaray.edu.tr ORCID ID https://orcid.org/oooo-0001-5938-3112

** Prof. Dr., İstanbul Ayvansaray Üniversitesi, Güzel Sanatlar, Tasarım ve Mimarlık Fakültesi, Gastronomi ve Mutfak Sanatları Bölümü, İstanbul, Türkiye,

E-posta: haydarozpinar@ayvansaray.edu.tr ORCID ID https://orcid.org/oooo-0002-2523-7149 
beslenme, gıda kalitesi ve gıda güvenliği, gıda işleme alanında birçok çalışma vardır. Özetle, hücre seviyesindeki genlerin, proteinlerin, enzimlerin, metabolitlerin ve mikro ortamların etkilerinin daha iyi anlaşılması, hücre fonksiyonlarını ve genel sağlığı geliştirmek için beslenme programlarının tasarımına metabolik yaklaşımlar yardımcı olabilir, sağlık ve hastalık, beslenme ve besinlerin rolünü anlayışımızı geliştirebilir. Bu çalışmanın amacı; gıda ve beslenme araştırmalarında metabolomic uygulamalar konusunda genel bir değerlendirme yapmak, bazı potansiyel uygulamaları vurgulamak, metabolominin gıda ve beslenme üzerindeki etkilerini araştırmak ve bu konularda bilimsel literatürü sunmaktır.

Anahtar Sözcükler: Metabolomik, gıda, beslenme, sağlık.

\title{
Metabolomic Applications in Nutrition and Food: A General Evaluation
}

\begin{abstract}
Metabolomics is the determination, quantification, and identification of small molecule metabolites from lipids, carbohydrates, vitamins, hormones and other cell components in tissues, cells, and physiological fluids by using high-efficiency technologies in a certain period. The application of metabolomics includes the identification of biomarkers, enzyme-substrate interactions, drug-activity studies, metabolic pathway analysis and some other studies related to the system biology. So metabolomics is the cheap and correct separation, definition and measurement of all metabolites in cells, tissues or biological fluids in short amounts of time with high throughput technologies such as NMR, GC-MS, and LC-MS. It is the quantitative measurement of the metabolic profile of the living being to characterize the genetics and the phenotypic response to the nutritional status of it. Environmental factors, such as feeding patterns and exposure to toxins, play an important role in the prevention/development of many diseases, such as obesity, type 2 diabetes, and therefore in the health status of individuals. There are many studies in the field of food science and nutrition, food quality and food safety and food processing. Being healthy is a combination of good genetics, good lifestyle and good nutrition. Metabolomics allows the analysis of physiological processes by monitoring metabolite concentration, they can vary according to metabolic information and to a substantial extent the molecular content of the food and its health properties and characterize the chemical changes as a result of food processing. In summary, a better understanding of the effects of genes, proteins, enzymes, metabolites at the cellular level and microenvironments can aid in metabolomic approach to the design of nutritional programs in order to process cell functions and improve overall health. Today, scientists are working to prevent obesity, diabetes, cardiovascular and chronic diseases and find new bioactive food components that prolong life, lose weight, improve physical and mental health, and prevent diseases such as heart attacks and cancer. In this
\end{abstract}


context, the use of metabolomics techniques, the development of food consumption patterns, the benefits of any diet and improvement of physiological responses are provided and new components can be discovered. In summary, a better understanding of the effects of cell-level genes, proteins, enzymes, metabolites, and micro-environments can help metabolic approaches to the design of nutritional programs to process cell functions and improve overall health and to improve our understanding of the role of health and disease, nutrition and nutrients. The objective of this study; to make a general evaluation about metabolomics applications in food and nutrition research and to emphasize some potential applications of metabolomics in food and nutrition research, to investigate the effects of metabolomics on nutrition and food to present scientific literature on these subjects.

Keywords: Metabolomics, food, nutrition, health.

\section{Giriş}

"Metabol” Yunanca bir kelimedir ve değissmek anlamındadır. "-ome” ise küme demektir¹. Bir hücre veya canlıdaki metabolizmanın tümü metabolom, metabolom çalışması ise, metabolomiktir ${ }^{1}$ Metabolomik, belirli bir zaman diliminde dokularda, hücrelerde ve fizyolojik sıvılarda lipid, karbohidratlar, vitaminler, hormonlar ve diğer hücre bileşenlerinden ortaya çıkan küçük moleküllü metabolitlerin yüksek verimli teknolojiler kullanılarak saptanması, miktarının belirlenmesi ve tanımlanmasıdır². Metabolitlerin karakterizasyonu sayesinde metabolizma ve moleküllerin parmak izi okuması sağlanabilir. Tüm metabolitlerin ayrıntılı ve kantitatif ölçümü hastalık teşhisi veya toksik ajanların fenotip üzerindeki etkilerini araştırmada en ideal yöntemdir ${ }^{1}$ Metabolomik analizleri; serum, idrar, beyin omurilik sıvısı, plazma, tükürük gibi vücut sıvılarındaki peptitler, aminoasitler, nükleik asitler, karbonhidratlar, organik asitler, vitaminler, polifenoller, alkoloidler, mineraller veya hücre ya da organizma tarafından sentezlenen, kullanılan veya sindirilen diğer kimyasal maddelerin analizleridir3.

Daha ayrıntılı bir tanımlama ile küçük moleküller peptitler, oligo-nükleotidler, șekerler, nükleozidler, organik asitler, ketonlar, aldehitler, aminler, amino asitler, lipitler, steroitler, alkaloidler ve ilaçlar, insan-bakteri ürünleri metabolitlerdir ve molekül ağırlıkları 1500 Da'un altındadır ${ }^{1}$ Insandaki metabolitlerin sayısı tam olarak 
bilinmemekte birlikte; en az iki bin-üç bin en fazla yirmi bin olacağı tahmin edilmektedir ${ }^{1}$.

İnsan genomunun tümüyle dizisinin çıkarılması, biyolojide omik teknolojileri denilen yeni bir çağ açmıştır. Omik terimi, biyolojik sistemlerin kapsamlı analizi olarak ifade edilmektedir ${ }^{1}$. Yeni omik teknolojileri ve biyoinformatik araçlar, beslenme, gıda ve metabolizma arasındaki karmaşık ilişkinin araştırılması konusunda çok büyük bir potansiyel sunmaktadır.

$\mathrm{Bu}$ derlemenin amacı, gıda ve beslenme araştırmalarında metabolomik uygulamalar konusunda genel bir değerlendirme yapmak, bazı potansiyel uygulamaları vurgulamak, metabolominin gıda ve beslenme üzerindeki etkilerini araştırmak ve bu konularda bilimsel literatürü sunmaktır.

\section{Metabolomiğin İlgili Olduğu Alanlar}

Metabolomik hastalık belirleyicisi olan veya tedavi denetimini sağlayan metabolitleri belirlemeyi amaçlar. Sözgelimi; hastanın metabolik profili ve genetik yapısına göre beslenme önerilerinde bulunulmasına imkân verir. Beslenme düzenleri ve toksinlere maruz kalma gibi diğer çevresel faktörler, obezite, tip 2 diyabet gibi birçok hastalı̆̆ın önlenmesinde/gelişmesinde ve dolayısıyla bireylerin sağlık durumlarında önemli bir rol oynamaktadır. Metabolik disfonksiyonun yeni erken biyolojik belirteçleri ve gelişmekte olan patolojilerin (obezite, metabolik sendrom, tip-2 diyabet, vb.) öngörücü biyobelirteçlerini keşfetmek için metabolomik araştırmalar yapılmaktadır. Ayrıca gıda bilimi alanında, gıda orijinalliği, gıda kalitesi ve gıda güvenliği ile gıda işleme çalışmalarında metabolomik teknikler kullanılmaktadır.

\section{Beslenme ve Gıda Araştırmalarında Metabolomik}

Tarihsel olarak, beslenme araştırmalarında bilim adamları çoğunlukla gıda metabolitlerinin analizlerine odaklanarak, azaltıcı bir yaklaşım kullanılır. Ancak gıdalarda bulunan kimyasal bileşenlerin ve karmaşık organizmaların biyokimyasal ağlar arasında oluşabilecek etkileşimlerini anlamak daha uygundur ${ }^{4}$. Sağlıklı olmak iyi genetik, iyi yaşam tarzı ve iyi beslenmenin bir kombinasyonudur. Metabolomik, metabolit konsantrasyonunun izlenmesi yoluyla fizyolojik süreçlerin analizine izin verir. 
Metabolomik ile gıda bileşenlerinin analizi yapılmakta, vücut sıvıları ve biyolojik dokularda bunların metabolitleri belirlenmekte, bunların biyolojik ve metabolizma, bağırsak mikroflorası rolünün değerlendirilmesi ve belirli bir beslenme programının fizyolojik tepkileri araştırılmaktadır ${ }^{5}$.

Metabolomik, yiyecek ve içecekleri daha detaylı inceler ve kimyasal yapılarında binlerce sonuç tespit edilir. Doğal ve doğal olmayan tüm gıda bileşenleri, genellikle "gıda metabolomu" olarak adlandırılır. Gıda metabolomu, beslenme ve sağlık arasındaki karmaşık etkileşimleri için önemli bilgiler sağlar ${ }^{6}$.

Son yıllarda yapılan çalışmalarda organik tarımla elde edilen ürünlerin, konvansiyonel tarımla elde edilen ürünlere göre çok daha fazla antioksidan, fenolik bileşikler içerdiği bulunmuştur7. Bilim adamları, metabolomik bilgiye ve gıda moleküler içeriğine göre; gıda işleme sonucunda oluşacak değişikliklerle daha besleyici gıdalar elde edebilirler ${ }^{8,9}$. Günümüzde kepekli makarnada fitosteroller, polikonasoller, doymamış yağ asitleri, aminoasitler, karotenoidler ve mineral bileşiklerin daha zengin olduğunu bulmak için kepekli ve rafine makarna örnekler arasında molekül farkı belirlemek için metabolomik bir yaklaşım kullanılmıştır ${ }^{9}$. Benzer uygulamalarda metabolomik, gıda dönüşümünün araştırılması için, etki göstermeye başlamaktadır ${ }^{8}$.

Gıda kaynaklı metabolitler hücre metabolizmasını başlıca üç mekanizma ile etkilerler. Bu mekanizmaları şu şekilde sıralayabiliriz; proteinler, enzimler ve mikro-etkileşimler. Çeşitli metabolitlere göre bir bileşim, doğrudan büyük makro moleküllerin kimyasalfiziksel özelliklerini belirler. Örneğin, hayvanların sinir zarlarının bileşimini değiştirmek için yapılan denemelerde, özellikle yağ asitleri içeren bir diyetle beslenenlerde değişim olduğu gösterilmiştir ${ }^{9}$. Değişmiş kompozisyon, membranların şekil ve esnekliğini ayrıca iyon kanalları ve zar içi proteinlerin fonksiyonlarını etkiler ve sonuçta, nörotransmisyon ve beyin gelişimi oluşur ${ }^{10}$.

Beslenme metabolitleri; enerji kaynağı sağlamak ve enerji metabolizması için yolakları düzenler. Örneğin, şekerler hali hazırda bu tür nükleotid adenozin trifosfat gibi enerji bakımından zengin metabolitlerin üretimi için sitrik asit döngüsü ve oksidatif fosforilasyon yollar aracılığıyla alt tabakalara glikoliz olarak girebilir. Sisteminde adenozin trifosfat aşırı olduğunda, şekerlerin metabolizması yağlı asit sentezinde rol 
oynar $^{11}$. Son zamanlarda yapılan araştırmalar, yüksek fruktozlu mısır şuruplu şeker bakımından zengin içeceklerin, yağlı karaciğer ve diyabet ve sonunda da kronik enflamatuar hastalıklara yol açtığına dair kanıtlar mevcuttur. Alternatif olarak, Bkompleks vitaminleri gibi diğer metabolitler, kofaktörler katalitik faaliyetleri değiştirerek veya görevlerinin yardımcı olarak enzimlerin bağlamasını sağlar. Örneğin, kofaktör tiyamin pirofosfat glikoliz kavşakta çoklu enzim kompleksi piruvat dehidrogenaz aktivitesi ve sitrik asit döngüsü dâhil olmak üzere birçok biyokimyasal reaksiyonları katalize eden tiaminin (B1 vitamini) türevidir. Beslenme metabolitleri haberci sinyal olarak hareket edebilirler. Örneğin, yă̆ asitleri metabolitleri biyokimyasal sinyallerin, iletici bağlanan ve sitosolik/nükleer reseptörlere veya zarbağlı G-protein reseptörlerini aktive edebilen, metabolitler, nükleik asitler (DNA), proteinler (histonlar), ve enzimler (histon deasetilazlar) olarak değiştirebilir ${ }^{12}$. Yani genetik kodunu yeniden programlar. Bu modifikasyonlar, hücre içi bölmelere ve asetilCoA'nın ve S-adenosilmetionin gibi metabolitlerin konsantrasyonunu düzenler. Son zamanlarda, bu tür nikotinamid adenin dinükleotit $(\mathrm{NAD}+)$ veya belli beslenme modelleri ile bağlantılı keton vücut beta hidroksibütirat enerji metabolit seviyelerinde bir dalgalanma gösterilmiştir. Örneğin açlık, kalori kısıtlaması ve düşük karbonhidratlı diyetler sonuçta hayvan modellerinde yaşam süresinin artması, enzim aktiviteleri ve gen ekspresyonunun modülasyonundan sorumlu olabilir ${ }^{13}$.

Bazı beslenme metabolitleri, oksidasyonun neden olduğu hasara sebep olan hücre kirleticilerinin azalmasına yönelik antioksidanlar gibi hareket ederek hücre metabolizmasını modüle eder. Antioksidanlar serbest radikaller, peroksitler, metaller ve oksijen ile etkileşimde bulunabilir. $\mathrm{Bu}$ şekilde, bu reaktif oksijen türlerinin oluşumunun ya da protein, lipid, DNA da dâhil olmak üzere hücrenin bütün bileşenlerine zarar verebilen oksidatif stres sinyali yayılmasını önler ${ }^{13}$. Özet olarak, gen, protein, enzim, hücresel düzeyde metabolitlerin mikro düzeyde etkilerinin daha iyi anlaşılması ve hücre fonksiyonlarına etkisi ile genel sağlığı artırmak amacıyla beslenme programları tasarımına metabolomik yaklaşım yardımcı olabilir ${ }^{13}$.

Belirli hastalıklar için epidemiyolojik çalışmalar beslenme alışkanlıkları ile önemli ölçüde kanser, kalp-damar hastalıkları ve Alzheimer hastalığı gibi bazı hastalıkların riskinin düşürebileceği görüşü vardır ${ }^{14}$. Günümüzde doğal antioksidanlar, 
vitaminler ve fitokimyasallar zenginleştirilmiş beslenme programları, düzenli tür gıda takviyelerine dair çalışmalar devam etmektedir ${ }^{3}$.

Bazı gıda maddelerinin tüketiminin koruyucu etkileri olabilir. Örneğin, kahve tüketimi nedeniyle kahvenin içinde bulunan antioksidanların muhtemel koroner kalp hastalığı riskini düşürmesi gibi. Ayrıca, nütrigenomik ve nutrigenetik araştırmalar, genetik varyasyonlar, bireylerin gıda kaynaklı bileşenlerin emilimini, metabolizmasını, atılımını ve biyolojik tepkisini değiştirebilir ${ }^{15}$. Örneğin, belirli bir genetik polimorfizm yani, kişinin hastalığa yakalanma riskinin, hastalığa verdiği yanıtın, ilaçlara karşı gözlenen yan etkilerin farklı olması; aynı zamanda sağlı̆̆ı etkileyebilir ${ }^{16}$. Bu kanttlarla, genomik ve metabolomik bir arada; bireyler için en uygun beslenme önerilerinin oluşturulabileceğini düşündürmektedir.

Protein ve karbonhidrat ile yağlar gıdaların büyük sınıflarından biridir, lipidler, suda çözünmezler. Lipidlerin metabolomik analizine lipidomikler adı verilir ${ }^{17}$. Lipidomikler, metabolomik çatısı altında olsa da lipidlerin farklı çözünürlük özellikleriyle genellikle metabolomik deneylerde onlardan ayrı analiz edilmektedir. Aslında, bu tür amino asitler ve nükleotidler gibi polar metabolitlere aksine, lipitler suda daha çok çözünür olan ve organik çözücüler ya da farklı, bir katı faz gibi ekstraksiyon prosedürleri kullanılarak biyolojik numunelerden ekstrakte edilmelidir. Lipidomik yaklaşımlar, omega-3 yağ asitleri karşı omega-6 oranı olarak lipidler beslenme dengesizlik veya eksikliklerin izlemek için uygun bir tanısal testlerin gelişimi için uygulanabilir.

Gıda bileşen analizleri, geleneksel olarak protein, yă̆, karbonhidrat, lif, vitamin, iz element, kuru madde ve kül gibi gıda bileşenlerinin belirlenmesi ve sınıflandırılmasıdır. Metabolit profili ile gıda bileşenlerinin belirlenmesi, gıda hilelerinin ve gıda kalitesinin tespiti amacıyla kullanılmaktadır. 2006 yılında gerçekleştirilen bir çalışmada, domates ve domates suyunda LC/MS ve NMR cihazları ile metabolit profili çıkarılmıştır. Ürünlerde 6o'dan fazla polar olmayan ve düşük düzeylerde tespit edilen polifenoller ve flavoglikozitler saptanmıştır ve sonuçlar domateslerin orijininin belirlenmesinde kullanılmıştır ${ }^{18}$.

Gıda hileleri özellikle meyve suyu ve sıvı yağlarda sıklıkla karşılaşılan olaylardır ${ }^{19}$. Bu kapsamda metabolit profili, diğer yöntemlerle yapılamayan ürüne özel karakteristiğin 
(aroma, renk, aminoasit profili, vitamin içeriği gibi) çıkarılması amacıyla kullanılarak, hileli ürünün kolayca tespit edilebilmesine olanak sağlamaktadır.

Son yıllarda gıda bilimcileri ve biyokimyacılar tarafından, insan sağlığının gelişimi ve sürekliliği için gerekli esansiyel gıda bileşenlerinin belirlenmesi adına önemli adımlar atılmıştır. Beslenme programları ile beslenme eksikliklerinin tedavisinde mineral ve vitaminler gibi zorunlu gıda takviyeleri sıklıkla kullanılmaktadır²0. Günümüzde beslenme bilimcileri obezite, diyabet, kardiyovasküler ve kronik hastalıkların önlenmesinde ve tedavisinde kullanılacak yeni yöntemler arayışındadır ${ }^{1}$. Aynı zamanda, yaşam süresini uzatan, kilo verdiren, fiziksel ve akıl sağlığını iyileştiren, kalp krizi, kanser gibi hastalıkları önleyen yeni biyoaktif gıda bileşenlerinin bulunması konusunda çalışmalar yapmaktadır. Metabolomik tekniklerin bu kapsamda kullanımı, gıda tüketim şekillerinin geliştirilmesi, herhangi bir diyet ve ilaç kullanımı karşısında alınan fizyolojik cevapların iyileştirilmesi gibi faydalar sağlanmakta ve yeni bileşenler keşfedilebilmektedir ${ }^{21,22}$.

Günümüzde gıda güvenliğinin sağlanması alanında en büyük problemler; kimyasal tehlikelerin orijini, mekanizmaları ve toksisitelerinin anlaşılabilmesi ve bunların uzak tutulmasını sağlayacak güvenilir araç ya da işlemlerin geliştirilebilmesi için yeni bir bilimsel görüşe ve çok kapsamlı araştırma programlarına gereksinim olduğudur. Gelişen yeni teknolojiler ve özellikle de metabolomik tekniği ile biyolojik sistemdeki tüm metabolitlerin tanımlanması ve miktarlarının belirlenmesi ile bu alana katkı sağlanacaktır²3.

Metabolomik teknikler beslenme durum ile klinik amaçlı biyobelirteçler çalışmalarında proteomik tekniklerle birlikte değerlendirilince daha etkin bilgiler sağlamaktadır. Hastalık teşhisinde açıklanamayan kısımlar metabolomikle etkili tedavi ve ilaç dozu ayarlamada da yardımcı olarak kullanılabilir ${ }^{24}$.

\section{Dünyada ve Türkiye'deki Bazı Metabolomik Çalışmalar}

\section{Dünyada Bazı Metabolomik Çalışmalar}

Ratlar üzerinde yapılan bir çalışmada tam tahıl $(n=10)$ veya rafine buğday unu $(n=10)$ içeren diyetler 2 hafta süre iki gruba uygulanmıştır. Tam tahıl tüketen gruba $60 \mathrm{~g} / 100 \mathrm{~g}$ tam tahıl unu, diğer gruba ise aynı miktarda rafine buğday unu verilmiştir. Oksidatif stres belirteçlerinden izoprostanlar ve malondialdehitler, E ve 
C vitamini ve lipit düzeyleri (karaciğer ve plazma trigliserit ve kolesterol) metabolomik tekniklerle ölçülmüşsür. Tam tahıl unu ile beslenen ratlarda idrarda, bazı trikarboksilik asit ara ürünlerinin, aromatik aminoasitlerin ve hippurik asidin anlamlı olarak daha yüksek olduğu böylece bazal metabolizma hızında değişikliğe yol açtı̆̆ı gösterilmiştir. Ayrıca, azaltılmış glutatyon ve betain seviyelerinin arttığı bildirilmiştir. Bu durum oksidatif stresin azaldığının ve iyi redoks durumunun bir işareti olarak kabul edilir²5.

Diyet düzenlerinin gruplandırıldığı ve 1003 kadının serum düzeylerinin üzerine etkilerini incelediği kapsamlı bir çalışmada, 163 metabolit incelenmiştir. Bu çalışmada gıda tüketim kayıtları alınarak 7 farklı parametre seçilmiştir. Bunlar kahve, sarımsak, sebze-meyve, alkol, kırmızı et tüketimi, düşük enerjili diyet ve geleneksel İngiliz diyetidir (kızarmış balık ve patates, et, tuzlu turtalar ve sebze tüketimi). Sarımsak, kahve, sebze alımı ile düşük enerji diyetler ve metabolit profili arasında bir korelasyon bulunmuştur. Bu diyet modellerinin bir sonucu olarak, plazma karnitinleri, gliserofosfolipitler ve sfingolipidlerin azaldığı bulunmuştur. Et tüketimi, yüksek alkol alımı ve geleneksel İngiliz diyeti ile bu metabolitler arasında bir ilişki bulunmamıştır²6.

Başka bir çalışmada 77 hafif obez bireye 8 hafta boyunca düşük enerjili diyet uygulanmıştır. Daha sonra bu bireyler rastgele iki gruba bölünmüş, biri yüksek glisemik indeksi olan grup ve diğeri düşük glisemik indeksi diyeti olan grup ve bunu takiben idrar örnekleri 6 hafta boyunca toplanmıştır. Her iki grubun metabolit profili, NMR tekniği kullanılarak incelenmiştir. Sonuç olarak, glisemik indeks ile Cpeptid seviyeleri arasında bir ilişki olmadığı gösterilmiştir ${ }^{27}$.

Obezite, prevalans ve insidansın artması ile son yıllarda önemli bir halk sağlı̆̆ problemi haline gelmiştir. Bununla birlikte, altta yatan biyokimyasal ve metabolik yollar tam olarak anlaşılmamıştır. Metabolik yaklaşım, obezite ile ilgili biyobelirteçlerin tanımlanması bu mekanizmaların netleştirilmesine yardımcı olur. Bir çalışmada, dallı zincirli amino asitler (DZAA), esterlenmemiş yağ asitleri, organik asitler, asilkarnitinler ve fosfolipitler obezite için potansiyel biyolojik ürünler olarak tanımlanmıştır. Bu, yüksek DZAA ile diğer amino asitler arasında obezite ile bir ilişki olduğunu göstermektedir. Ayrıca, $\beta$-oksidasyon deregülasyonunun obezitenin gelişimi ile ilişkili olduğu bildirilmiştir ${ }^{28}$. 


\section{Türkiye'deki Bazı Metabolomik Çalışmalar}

D vitamini hakkında doğru klinik yorum yapabilmek için total 25 (OH) D düzeylerinin yanı sıra serbest/biyoyararlanılabilir formlar, D vitamini bağlayıcı protein (DBP), parathormon ve 1,25(OH)2D3, 3-epi-25(OH)D, 24,25(OH)2D3 gibi çeşitli metabolitlerin de bilinmesi gereklidir. D vitamini metabolitlerinin hastalıklardaki ve beslenme durumundaki etkilerini belirlenmesi için yapılan metabolomik çalışmalarda, kolekalsiferol veya ergokalsiferol ile yapılan tedavi etkinliklerinin değerlendirilmesi kolaylaşmaktadır. Metabolomik, tüm D vitamini metabolitlerini kapsayacak nitelikte, evrensel ve standart bir analitik yöntem olarak değerlendirilmiştir29.

Hızla kilo verilmesine neden olduğu söylenen zayıflama tabletlerinin günümüzde kullanımı oldukça popülerdir ve Çin kökenli bitkisel zayıflama tabletlerinde kullanılan aristoloşik asitin ratlarda kemik iliğinde gen düzeyinde zararlı olduğu ve gen mutasyonu ile ilişkili olduğu başka bir çalışmada metabolomik yöntemlerle gösterilmiştirº.

\section{Sonuç ve Öneriler}

Metabolomik gıda biliminde; gıda hilelerinin ve gıda kalitesinin tespiti, moleküler gıda kompozisyonunun belirlenmesinde kullanılabilir. Günümüzde metabolomik teknoloji ile yüzlerce hatta binlerce farklı kimyasal bileşen tespit edilebilmektedir. Metabolomikle aynı zamanda beslenmede kişiselleştirmeye doğru adım atılabilir ${ }^{23}$. Beslenme yoluyla hastalıkların önlenmesi ve tedavisinde metaboloma dayalı olarak belirli gruplar halinde bireylerin sınıflandırılması, beslenme gereksinimlerini, bireysel farklılıkları tanımlamak ve böyle bir strateji ile bireysel beslenme ihtiyaçlarına uygun kişiselleştirilmiş beslenme programları geliştirilmesini koruyucu hekimlik uygulamalarına da hizmet ederek ileride belki de rutin bir analiz ve öngörü yöntemi haline dönüşebilir. Spesifik kan metaboliti profili testleri ile beslenme eksikliği ya da hastalık için risk altında olan kişiler tespit edilebilir. İnsanların idrar ve plazma örneklerinden yararlanılarak organizmada oluşan metabolitlerin miktarları ile besleme kaynaklı ekzojen metabolitlerin miktarları ölçülebilir. 
Sonuç olarak kimyasal tehlikelerin orijini, mekanizmaları ve toksisitelerinin anlaşılabilmesi ve bunların uzak tutulmasını sağlayacak güvenilir araç ya da işlemlerin geliştirilebilmesi için yeni bir bilimsel görüşe ve çok kapsamlı araştırmaların yapılması ve hücre seviyesindeki genlerin, proteinlerin, enzimlerin, metabolitlerin ve mikro ortamların etkilerinin daha iyi anlaşılması, hücre fonksiyonlarını ve genel sağlı̆̆ geliştirmek için beslenme programlarının tasarımında ve beslenmede kişiselleştirmeye gidilmesinde metabolik yaklaşımlar yardımcı olabilir, sağlık ve hastalık, beslenme ve besinlerin rolü konusunda anlayışımızı geliştirebilir.

Yeni olan bu teknolojinin üzerine daha fazla araştırmanın yapılması ve endüstriyel uygulamaların bilim ışı̆̆ı altında yürütülmesi ile güzel sonuçlara ulaşılması mümkün olabilir yine de metabolomik konusunda pek çok alanda gelişmeye ihtiyaç duyulmaktadır.

\section{KAYNAKLAR}

1. Gibney MJ, Walsh M, Brennan L, Roche HM, German B, Ommen B. Metabolomics in human nutrition: opportunities and challenges. Am J Clin Nutr. 2005;82:497-503.

2. Goodacre R. Metabolomics-the way forward. Metabolomics. 2005;1:1-2.

3. Manach C, Hubert J, Llorach R, Scalbert A. The complex links between dietary phytochemicals and human health deciphered by metabolomics. Mol Nutr Food. 2009;53:1303-1315.

4. Primrose S, Draper J, Elsom R, et al. Metabolomics and human nutrition. $\mathrm{Br}$ J Nutr. 2011;105:1277-1283.

5. Llorach R, Garcia-Aloy M, Tulipani S, Vazquez-Fresno R, Andres-Lacueva C. Nutrimetabolomic strategies to develop new biomarkers of intake and health effects. $J$ Agric Food Chem. 2012;60:8797-8808.

6. Rubio-Aliaga I, Kochhar S, Silva-Zolezzi I. Biomarkers of nutrient bioactivity and efficacy: a route toward personalized nutrition. J Clin Gastroenterol. 2012;46:545-554. 
7. Novotna H, Kmiecik O, Galazka M, et al. Metabolomic fingerprinting employing DART-TOFMS for authentication of tomatoes and peppers from organic and conventional farming. Food Addit Contam Part A Chem Anal Control Expo Risk Assess. 2012;29:1335-1346.

8. Heuberger AL, Lewis MR, Chen MH, Brick MA, Leach JE, Ryan EP. Metabolomic and functional genomic analyses reveal varietal differences in bioactive compounds of cooked rice. Plos One. 2010;5:2915.

9. Beleggia R, Platani C, Papa R, et al. Metabolomics and food processing: from semolina to pasta. J Agric Food Chem. 2011;59:9366-9377.

10. Rapoport SI, Ramadan E, Basselin M. Docosahexaenoic acid (DHA) incorporation into the brain from plasma, as an in vivo biomarker of brain DHA metabolism and neurotransmission. Prostaglandins Other Lipid Mediat. 2011;96:109-113.

11. Bocarsly ME, Powell ES, Avena NM, Hoebel BG. High-fructose corn syrup causes characteristics of obesity in rats: increased body weight, body fat and triglyceride levels. Pharmacol Biochem Behav. 2010;97:101-106.

12. Ong TP, Perusse L. Impact of nutritional epigenomics on disease risk and prevention: introduction. $J$ Nutrigenet Nutrigenomics. 2011;4:245-247.

13. Sassone-Corsi P. Physiology. When metabolism and epigenetics converge. Science. 2013;339:148-150.

14. Snigdha S, Astarita G, Piomelli D, Cotman CW. Effects of diet and behavioral enrichment on free fatty acids in the aged canine brain. Neuroscience. 2012;202:326-333.

15. Cuda C, Badawi A, Karmali M, El-Sohemy A. Polymorphisms in Toll-like receptor 4 are associated with factors of the metabolic syndrome and modify the association between dietary saturated fat and fasting high-density lipoprotein cholesterol. Metabolism. 2011;60:1131-1135.

16. Cornelis MC, El-Sohemy A. Coffee, caffeine, and coronary heart disease. Curr Opin Clin Nutr Metab Care. 2007;10:745-751.

17. Wenk MR. The emerging field of lipidomics. Nat Rev Drug Discov. 2005;4:594-610. 
18. Moco S, Bino RJ, Vorst O, Verhoeven HA, Groot J, Beek TA. A liquid chromatography-mas spectrometry-based metabolome database for tomato. Plant Physiol. 2006;141:1205-1218.

19. Ogrinc N, Kosir IJ, Spangenberg JE, Kidric J. The application of NMR and MS methods for detection of adulteration of wine, fruit juices and olive oil. Anal Bioanal Chem. 2003;376:424-430.

20. Lindon JC, Holmes E, Bollard ME, Stanley EG, Nicholson JK. Metabonomics technologies and their applications in physiological monitoring, drug safety assessment and disease diagnosis. Biomarkers.2013;9:1-31.

21. Christopher J, Haselssen JN. Metabolic profiling as a tool for understanding mechanisms of toxicity. Toxicol Pathol. 2008;36(1):140-147.

22. Sébédio JL. Metabolomics, nutrition, and potential biomarkers of food quality, intake, and health status. Adv Food Nutr Res. 2017;82:83-116.

23. Wishart DS, Tzur D, Knox C, et al. HMDB: the human metabolome database. Nucleic Acids Res. 2007;35:521-526.

24. Öztürk AS. The clinical aproach to metabolomics and proteomics concepts. Turkiye Klinikleri J Vet Sci Intern Med-Special Topics. 2015;1(1):31-39.

25. Fardet A, Canlet C, Gottardi G, et al. Whole-Grain and Refined Wheat Flours Show Distinct Metabolic Profiles in Rats as Assessed by a $1 \mathrm{H}$ NMR-Based Metabonomic Approach. J Nutr. 2007;137(4):923-929.

26. Menni C, Zhai G, Macgregor A, et al. Targeted metabolomics profiles are strongly correlated with nutritional patterns in women. Metabolomics. 2013;9(2):506514.

27. Rasmussen LG, Winning H, Savorani F, et al. Assessment of dietary exposure related to dietary GI and fibre intake in a nutritional metabolomic study of human urine. Genes Nutr. 2012;7(2):281-293.

28. Rauschert S, Uhl O, Koletzko B, Hellmuth C. Metabolomic biomarkers for obesity in humans: a short review. Ann. Nutr. Metab. 2014;64(3-4):314-324.

29. Karatoy B, Akbas EH. D Vitamini ve Metabolomik. Türk Klinik Biyokimya Derg. 2018;16(2):127-194.

3o. Yaman Ö. Hekimlikte metabolomik çalışmalara genel bir bakış. Journal of Bahri Dagdas Animal Research. 2015;3(1):33-46. 